\title{
Is the use of AGILE patency capsule prior to videocapsule endoscopy useful in all patients with spondyloarthritis?
}

\author{
ANDRADA GHEORGHE ${ }^{1}$, DENISE CARMEN MIHAELA ZAHIU ${ }^{1}$, THEODOR ALEXANDRU VOIOSU ${ }^{1,2}$, \\ BOGDAN RADU MATEESCU ${ }^{1,2}$, MIHAIL RADU VOIOSU ${ }^{1,2}$, MIHAI RIMBAŞ ${ }^{1,2}$ \\ ${ }^{1}$ Gastroenterology Department, "Colentina” Clinical Hospital, Bucharest, Romania \\ ${ }^{2}$ Internal Medicine Department, "Carol Davila” University of Medicine, Bucharest, Romania
}

\begin{abstract}
Background and aims. As already known, spondyloarthritis patients present a striking resemblance in intestinal inflammation with early Crohn's disease. Moreover, the frequent use of nonsteroidal anti-inflammatory drugs is an important part of their treatment. Both conditions could lead to intestinal stenoses. Therefore we proposed to investigate the usefulness of the patency capsule test in patients with spondyloarthritis.

Material and methods. 64 consecutive patients (33 males; mean age $38 \pm 11$ years) that fulfilled the AMOR criteria for seronegative spondyloarthropathy (59.4\% ankylosing spondylitis) lacking symptoms or signs of intestinal stenosis were enrolled and submitted to an AGILETM capsule patency test followed by a video capsule endoscopy (PillCam SB2 ${ }^{\mathrm{TM}}$ ), as part of a protocol investigating the presence of intestinal inflammatory lesions. After reviewing the VCE recordings, the Lewis score (of small bowel inflammatory involvement) was computed.

Results. In only 5 patients $(7.8 \%)$ of the study group, the luminal patency test was negative. However, there was no retention of the videocapsule in any of the patients. From the 59 patients with a positive patency test, 3 patients presented single small bowel stenoses (two with ulcerated overlying inflamed mucosa, one cicatricial), all being traversed by the videocapsule along the length of the recording. None of the patients with a negative test had bowel stenoses. There was no correlation between the patency test and the Lewis score, the $\mathrm{C}$ reactive protein value, diagnosis of inflammatory bowel disease, or the family history of spondyloarthritis, psoriasis or inflammatory bowel disease.

Conclusion. The AGILE patency capsule does not seem to be a useful tool for all patients with spondyloarthritis prior to small bowel videocapsule endoscopy (ClinicalTrial.gov ID NCT 00768950).
\end{abstract}

Keywords: spondyloarthritis, patency capsule, AGILE, videocapsule endoscopy.

\section{INTRODUCTION}

Videocapsule endoscopy (VCE) is the least invasive tool used for examining in detail the entire mucosa of the small bowel. It is the primary diagnostic procedure in order to evaluate small bowel lesions, although it has a small risk of retention in case of a stenosis. In order to avoid putting the patient through a risky procedure, the patency capsule was designed, with the same shape and size as the small bowel endoscopic videocapsule [1]. The AGILE patency capsule (Given Imaging, Yokneam, Israel) is a new dissolvable capsule that supposedly provides a simple way of identifying the patency of the gastrointestinal tract before VCE. The device is meant to dissolve itself 30 hours after being ingested, its intact excretion offering an evidence of the intestinal luminal patency, thus allowing a safe VCE examination [2].

Spondyloarthritis ( $\mathrm{SpA})$ is a term applied to a group of rheumatic conditions with common features, the main ones being the association with $H L A-B 27$, an asymmetric pattern of peripheral arthritis, enthesitis and dactylitis [3]. Although most of the patients do not present any clinical intestinal symptoms [4], there is a strong relationship between $\mathrm{SpA}$ and inflammatory bowel disease (IBD). Up to two thirds of the patients with SpA have histological small bowel inflammation [5] and around $8 \%$ of patients with ankylosing spondylitis develop clinically overt inflammatory bowel disease, especially Crohn's disease [4]. Moreover, roughly two thirds of the patients who are taking nonsteroidal antiinflammatory drugs (NSAIDs) - including most of 
the SpA patients - have intestinal inflammation [6], that could progress in some cases to small bowel stenosis [7].

Given the above premises, the aim of the study was to assess whether the intestinal luminal patency test is correlated with the intestinal inflamematory involvement, and whether it should be a routine procedure for all patients with spondyloarthritis before VCE examination of the small bowel in this population, in order to avoid the risks associated with VCE retention.

\section{MATERIAL AND METHODS}

This study is a part of a single-center research aiming to investigate the bowel inflammatory involvement in spondyloarthritis, registered on Clinicaltrials.gov with the number NCT00768950. Between January 2008 and December 2013, consecutive patients that have completed the AMOR criteria for seronegative spondyloarthropathy were included in the study, with any of the following diagnoses: psoriatic arthritis, ankylosing spondylitis, reactive arthritis, Behçet's disease-associated spondyloarthritis, and undifferentiated spondyloarthritis. History of major abdominal surgery or radiotherapy at the level of pelvis or abdomen, patients with known inflammatory bowel disease or with symptoms suggestive of intestinal obstruction, presence of swallowing disorders, presence of cardiac pacemakers and pregnant women represented exclusion criteria.

Study procedures included first a small bowel patency test using the AGILETM capsule (Given Imaging, Yokneam, Israel). For this, every patient had to comply with a liquid diet for 24 hours prior to the administration of the patency capsule and remained fasting 12 hours prior to the test. Immediately after swallowing of the patency capsule, its presence in the abdomen was demonstrated with the dedicated scanner. The patients were monitored in order to record any possible intestinal obstruction symptoms until it was certified that the patency capsule was excreted. Testing with the dedicated scanner was performed 30 hours from swallowing the patency capsule, and, if the test was negative, again 8 hours later. A positive test was defined as the intact excretion of the patency capsule or its elimination in the 38 hours interval from swallowing. This was certified with its direct visualization in the stool and/or absence of its identification within the abdomen with the scanner. A negative test meant the absence of the excretion of the capsule in the 38 hours interval from swallowing or absence of its intact excretion afterwards.

The AGILE patency test was followed by the VCE examination of the small bowel (PillCam SB2 or SB2L (Given Imaging, Yokneam, Israel), the latter with 1 hour longer battery life, using a standard protocol, with 2 liters of polyethylene glycol solution administered in the evening before the procedure and 1 liter in the early morning of the procedure (Endofalk, Dr. Falk Pharma GmbH, Freiburg, Germany). The inflammatory involvement of the small bowel mucosa was quantified with the Lewis score (computed aided by the reading software). Data regarding NSAID consumption, $C$ reactive protein value, smoking history or the family history of spondyloarthritis, psoriasis or inflammatory bowel disease were recorded. A follow-up interview was performed at the end of the study with the referring physician, or, when this was not possible, with the patient, asking about evolution towards overt IBD.

The statistical software package SPSS for Windows Version 16.0 (SPSS Inc., Chicago, IL) was used for the statistical analysis of the data. Hypothesis testing was 2-tailed, and $p$ value $<0.05$ was considered statistically significant.

\section{RESULTS}

In the timeline of 5 years, 70 possible candidates for the study were identified. Among them, 4 patients refused to participate, thus 66 underwent the AGILE patency test. After the patency test, 2 patients with a negative test refused to remain in the study and to undergo the videocapsule endoscopy examination. Therefore, the study is based on the analysis of data from 64 patients.

From the 64 patients that underwent a patency test, $51.6 \%$ (33) were males. The mean age of the group was $38 \pm 11$ years. The main diagnosis was ankylosing spondylitis for $38(59.4 \%)$ of the patients, followed by undifferentiated spondyloarthritis in $16(25.0 \%)$, psoriatic spondyloarthritis 
in $3(4.7 \%)$ and Behçet's disease associated spondyloarthritis in 7 (10.9\%).

In 5 patients $(7.8 \%)$ of the study group, the luminal patency test was negative (the Agile capsule was not excreted intact or in the range of 38 hours after ingestion) (see also Figure 1). All 64 patients (including these 5) underwent the VCE examination and in all the VCE was excreted later without incidents.

For the whole bowel, the Lewis score could be calculated for 63 patients $(98.4 \%)$. Of them, 51 patients $(80.9 \%)$ had intestinal inflammatory lesions of the small bowel (Lewis score 135 or more). These changes were considered mild (score $<790$ ) for 45 patients (71.4\%) and moderate-severe (score $\geq$ 790) for 6 patients $(9.5 \%)$.

3 patients had single small bowel stenoses, two with ulcerated overlying mucosa, all being traversed by the videocapsule along the length of the recording; in one of these patients the VCE did not reach the colon till the end of the recording, but it was excreted later without incidents. None of these 3 patients had a negative patency test, and none of them had any signs or symptoms of intestinal obstruction.
The intestinal patency test was not correlated with the intestinal inflammatory involvement (the Lewis score, $p=0.95$ ) (Figure 2) or small bowel transit times $(p=0.53)$ (Figure 3). From the study group, 35 patients $(54.7 \%)$ were currently treated with at least one non-steroidal anti-inflammatory drug. However, the AGILE ${ }^{\mathrm{TM}}$ patency test was not correlated with concomitant NSAID treatment $(\mathrm{p}=$ 0.36).

The AGILE patency test was also not correlated with the $\mathrm{C}$ reactive protein value $(\mathrm{p}=$ $0.35)$, current smoking $(p=0.65)$ or the family history of spondyloarthritis, psoriasis or inflammatory bowel disease $(\mathrm{p}=0.28)$.

Follow-up was performed for 47 patients $(73.4 \%)$ at a mean interval of 683 days (range $23-$ 1427) from the study procedures. Of the study cohort, 8 patients $(12.5 \%)$ were initially diagnosed or had evolution towards overt IBD (7 Crohn's disease and 1 ulcerative colitis). From these patients, 1 had a negative patency test and 2 had a small bowel stenosis identified as part of the present study protocol. The AGILE patency test was however not correlated with the diagnosis of overt $\operatorname{IBD}(\mathrm{p}=0.53)$.

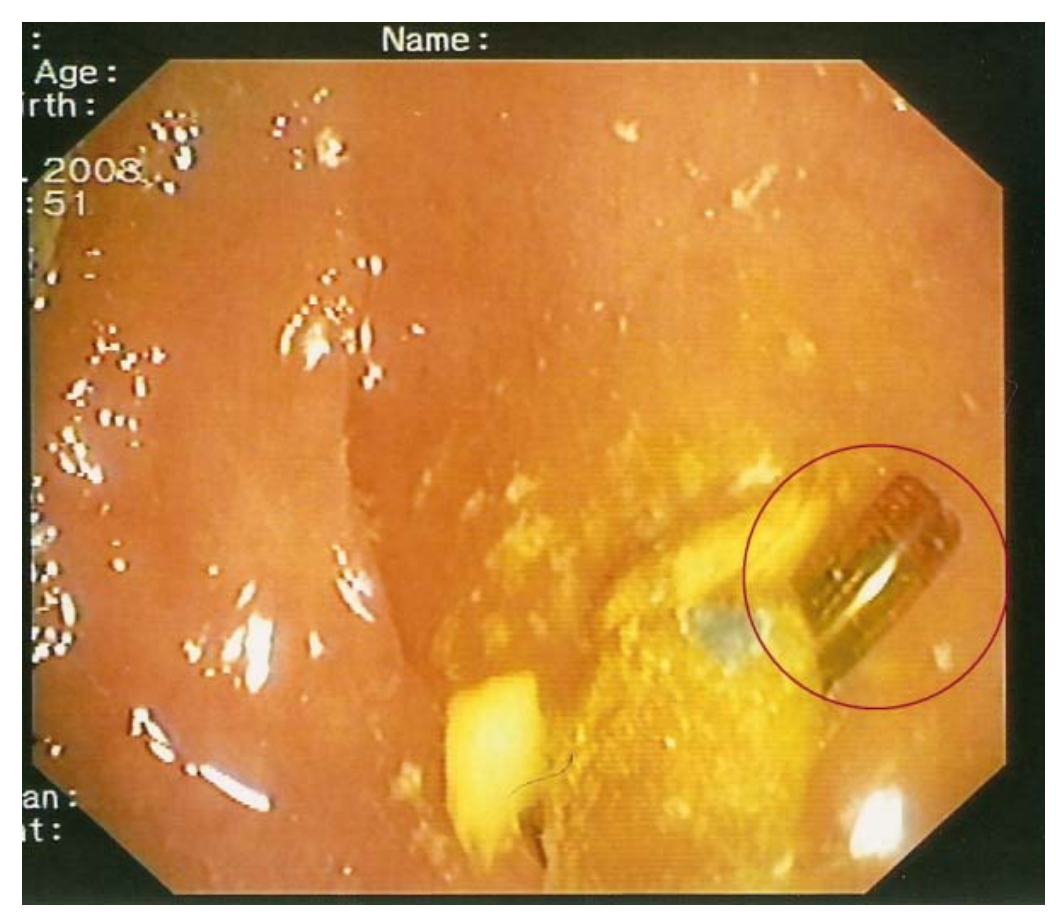

Figure 1. Fragments of an Agile capsule 50 hours after its ingestion (encircled), shown in the cecum during colonoscopy. The patient also underwent PillCam SB2 videocapsule endoscopic examination, procedure that went without incidents (after a luminal intestinal patency negative test). 


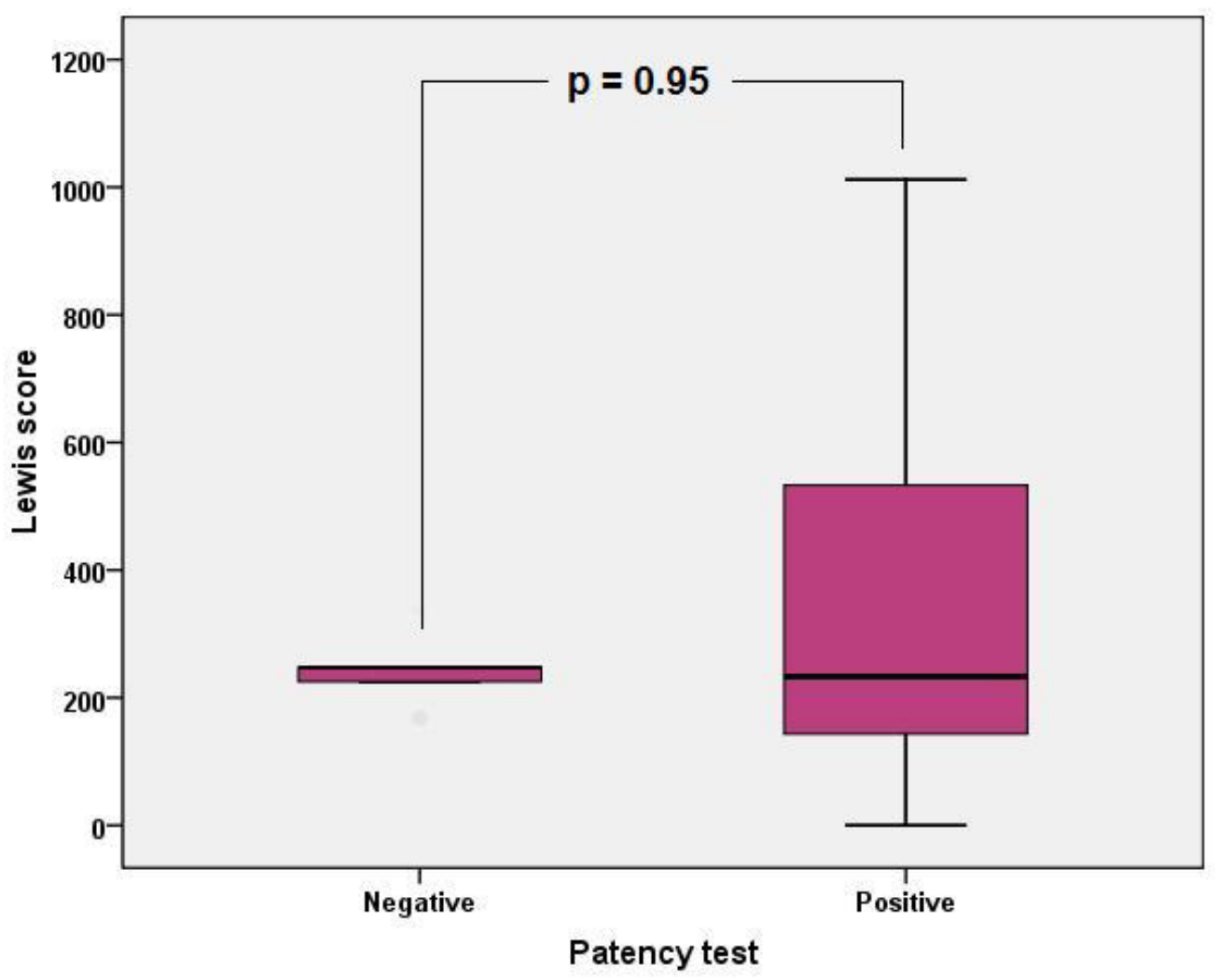

Figure 2. Comparison between Lewis scores in patients with negative and positive luminal intestinal patency tests.

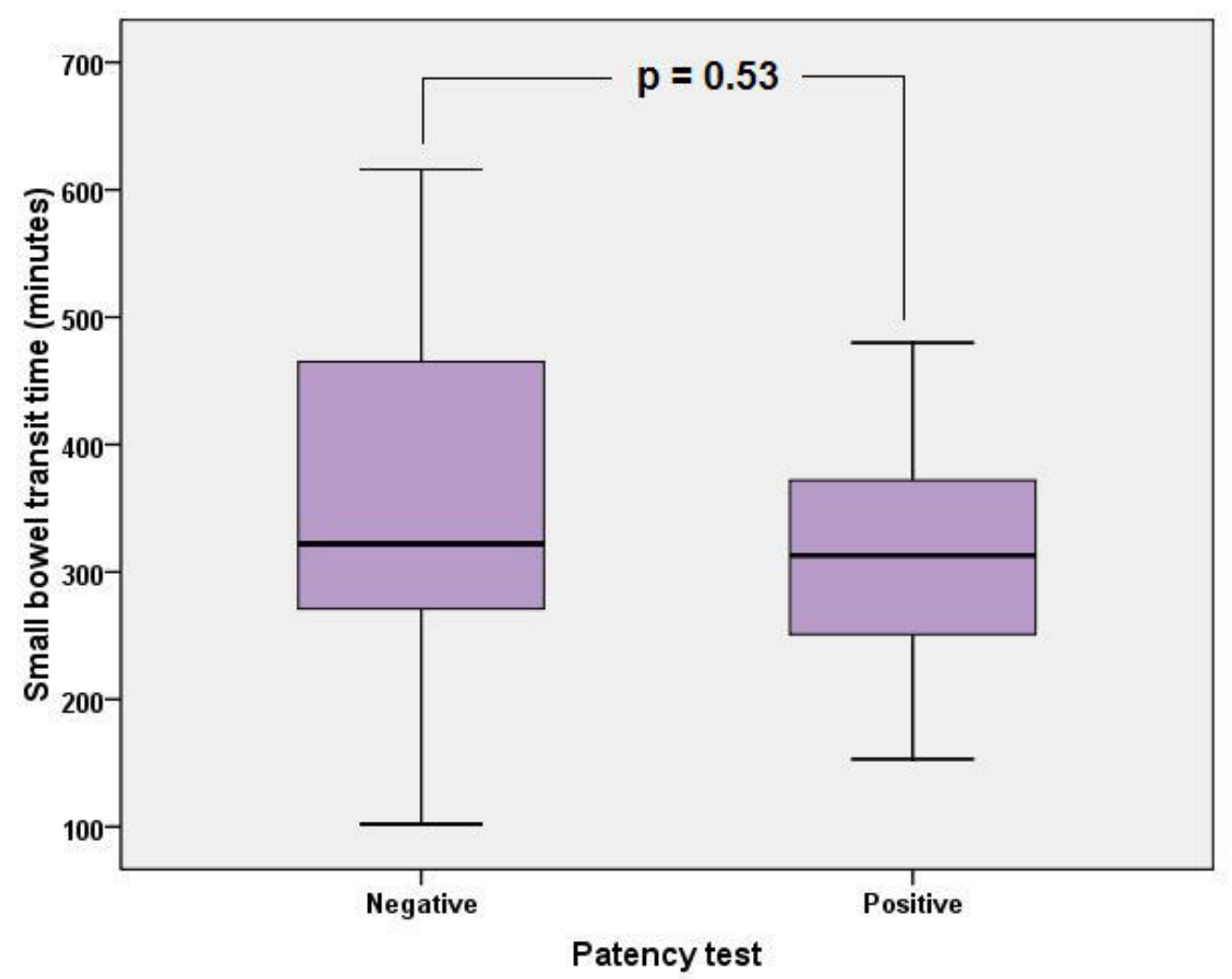

Figure 3. Comparison between videocapsule endoscopy small bowel transit times in patients with negative and positive luminal intestinal patency tests. 


\section{DISCUSSION}

Spondyloarthritis $(\mathrm{SpA})$ is a group of chronic inflammatory diseases that can have, besides the spinal and articular manifestations, extraarticular involvement, being frequently associated with uveitis, psoriasis and small bowel inflammatory lesions. There is a percentage of 5-10\% of patients with SpA that will develop inflammatory bowel disease and a much higher percentage, close to $60 \%$ of patients that have asymptomatic bowel inflammatory lesions [8]. But despite this evidence, in these patients an endoscopic assessment of the entirety of the small bowel is not performed in a systematic manner. However, due to the high percentage of small bowel involvement, and the association with IBD, we believe that all symptomatic patients should undergo endoscopic evaluation with or without a previous stool calprotectin test determination.

Video capsule endoscopy is being more and more used to investigate small bowel pathology. It has been used since 2001 and it has proved useful to diagnose small bowel Crohn's disease, small bowel neoplasia or vascular mucosal lesions, celiac disease or drug-induced small bowel injury. The procedure is associated with one major complication, which is capsule retention, still rarely causing bowel obstruction or perforation, but that can require surgical treatment to remove the retained videocapsule. It is not a frequent complication, since in a review of 1000 VCE procedures, there was a retention rate of $1.4 \%$ and none of the patients had any symptoms [9]. However, videocapsule retention requiring surgical or endoscopic removal occurs most commonly in patients with Crohn's disease or small bowel diaphragms associated with the use of NSAIDs [10]. The retention rate is between $4-13 \%$ in those with known Crohn's disease [11-13] and between $1-2 \%$ in patients with suspicion of this disease [13-15]. As regards small bowel diaphragms produced by NSAIDs, this has resulted in the retention of the videocapsule at a rate of $1.1 \%$ in 1,000 patients with various indications for examination with endoscopic videocapsule analyzed in a retrospective study [16]. Characteristic diaphragm-like strictures are said to be a result of chronic ulcers caused by NSAID, and in this regard it has been reported that $17 \%$ of patients with NSAID-induced small bowel ulcers can develop such stenoses [17]. On the other hand, the rate of non-excretion was zero in healthy asymptomatic volunteers [18].
Given the above risks, our aim was to establish whether the patency test is necessary to be done for all patients with spondyloarthritis, including patients with no symptoms or signs of stenosis or obstruction that will undergo small bowel videocapsule endoscopy. The patency capsule is made out of lactose mixed with $10 \%$ barium with wax plugs at the ends. It has the same dimensions as the PillCam SB videocapsule, the essential difference being that it starts to dissolve after 30 hours. It is meant to be detected with radiofrequency scanner or with radiography [19].

According to an analysis of published cases of suspected small bowel stricture, in which 203 patients were included, the patency capsule has a very high sensitivity (97\%) and a specificity $(83 \%)$ of confirming the patency of the gastrointestinal tract before videocapsule endoscopy examination [20]. Importantly, it is not a risk-free procedure, as there have been reported cases of temporary intestinal occlusion and in a study conducted on 22 patients evaluating the usefulness of the patency capsule in patients with suspected small bowel stenosis, 3 patients had intestinal occlusion which required emergency surgery in 2 [21].

In our study we enrolled all patients with SpA, including some that were consequently diagnosed with Crohn's disease. Patients with SpA are prone to develop Crohn's disease, on the one hand, and on the other, by the frequent use of NSAIDs, which can cause intestinal strictures, are at risk of videocapsule retention. Based on literature data, taking into account the prevalence of inflammatory bowel disease of about $5 \%$ in patients with SpA (and a risk of retention of the videocapsule in these cases of around 10\%) and the rate of occurrence of diaphragm disease (around $1 \%$ in those who chronically take NSAIDs, as is the case in about $50 \%$ of patients with $\mathrm{SpA}$ ), the risk of videocapsule retention to which patients with SpA would be subjected to would be around $1 \%$, event that did not happen in the present study.

All the patients in the present study took the patency test prior to the VCE. In $92.2 \%$ of our patients the patency test was positive, although 3 of these patients had intestinal stenoses, while for the $7.8 \%$ of patients with negative patency test the VCE did not record any sign of small bowel stenosis. In other words, on a study population of 64 individuals with different forms of spondyloarthritides with no symptoms suggestive of bowel strictures, the AGILE patency capsule was not 
useful in identifying patients at risk for small bowel videocapsule retention.

However, to the retention risk were subjected especially those 5 patients $(7.8 \%)$ with a negative patency test, who, after they have been explained the potential risks, agreed to continue the procedures in the study, fortunately without incidents. The patency capsule test was also not correlated with the inflammatory intestinal involvement, use of NSAIDs, VCE small bowel transit times, smoking or diagnosis of inflammatory bowel disease.
In conclusion, these results suggest that the patency capsule is not a useful tool to be used before video capsule endoscopy in all patients with spondyloarthritis who do not have any symptoms or signs of small bowel stenoses. To what extent, however, the use of such a test would be justified in patients with spondyloarthritis, in order to avoid a theoretic videocapsule retention risk of $1 \%$, remains to be proven. The patency capsule test should therefore for the present time be limited to patients with known or suspected small bowel strictures.

Introducere şi obiective. Este bine cunoscut faptul că pacienții cu spondiloartrite seronegative prezintă inflamație intestinală similară celei din boala Crohn incipientă. In plus, utilizarea frecventă a tratamentului cu medicamente antiinflamatoare nesteroidiene este o parte importantă a tratamentului acestor pacienți. Ambele circumstanțe pot duce la apariția de stenoze intestinale. Prin urmare, propunem investigarea utilității testului cu capsula de patență a pacienților cu spondiloartrite seronegative.

Material şi metode. 64 de pacienți (33 bărbați, vârstă medie $38 \pm 11$ ani) care au indeplinit criteriile AMOR pentru spondiloartropatii seronegative $(59.4 \%$ spondilită anchilozantă), care nu prezentau niciun simptom sau semne sugestive de stenoză intestinală au fost înrolați şi supuşi testului cu capsula de patență AGILE ${ }^{\mathrm{TM}}$, care a fost urmat de examinarea endoscopică a intestinului subțire cu videocapsulă (PillCam SB2 ${ }^{\mathrm{TM}}$ ), ca parte a unui protocol vizând detecția prezenței leziunilor intestinale inflamatorii. După analizarea înregistrărilor de videocapsulă, scorul Lewis (de afectare inflamatorie a intestinului subțire) a fost calculat pentru fiecare pacient.

Rezultate. La doar 5 pacienți (7.8\%) din grupul de studiu, testul de patență a intestinului a fost negativ. Cu toate acestea, nu a existat niciun caz de retenție a videocapsulei printre aceşti pacienți. Dintre cei 59 de pacienți cu test de patență pozitiv, 3 pacienți au prezentat leziuni stenozante singulare la nivelul intestinului subțire (două cu mucoasa de acoperire ulcerată, una cu aspect cicatricial), toate fiind traversate de către videocapsula endoscopică pe parcursul înregistrării. Niciun pacient cu test de patență negativă nu a prezentat vreo stenoză intestinală. $\mathrm{Nu}$ a existat nicio corelație între testul de patență intestinală, scorul Lewis, valoarea proteinei $C$ reactive serice, diagnosticul de boală inflamatorie intestinală sau istoricul familial de spondiloartrită, psoriazis sau boală inflamatorie intestinală.

Concluzie. Testul cu capsula de patență AGILE ${ }^{\mathrm{TM}}$ efectuat înaintea endoscopiei cu videocapsulă a intestinului subțire nu pare a fi util pentru pacienții cu spondiloartrite seronegative (ClinicalTrial.gov ID NCT 00768950).

Correspondence to: Mihai Rimbaş MD, PhD, Gastroenterology Department, "Colentina" Clinical Hospital, 19-21 Ştefan cel Mare Street, 020125, Bucharest, Romania, Tel: +40 723232052, Fax: +40 318162376 E-mail: mrimbas@gmail.com 


\section{REFERENCES}

1. FORK F.T., KARLSSON N., KADHEM S., OHLSSON B., Small bowel enteroclysis with magnetic resonance imaging and computed tomography in patients with failed and uncertain passage of a patency capsule. BMC Med Imaging. 2012; 12:3.

2. CAUNEDO-ALVAREZ A., ROMERO-VAZQUEZ J., HERRERIAS-GUTIERREZ J.M., Patency and Agile capsules. World J Gastroenterol 2008; 14:5269-73.

3. HEALY P.J., HELLIWELL P.S., Classification of the spondyloarthropathies. Curr Opin Rheumatol 2005; 17(4):395-399.

4. MIELANTS H., VEYS EM., CUVELIER C., DE VOS M., GOEMAERE S., DE CLERCQ L., et al., The evolution of spondylarthropathies in relation to gut histology: Part III. Prospective study of the clinical evolution of spondylarthropathies in relation to the evolution of gut histology. J Rheumatol 1995; 22:2279-2284.

5. DE KEYSER, BAETEN D., VAN DEN BOSCH F., DE VOS M., CUVLIER C., MIELANTS H., et al., Gut inflammation and spondyloarthropathies. Curr Rheumatol Rep 2002; 4:525-32.

6. DAVIES N.M., Toxicity of nonsteroidal anti-inflammatory drugs in the large intestine. Dis Colon Rectum 1995; 38:1311-21.

7. LADAS S.D., TRIANTAFYLLOU K., SPADA C., RICCIONI M.E., REY J.F., NIV Y., et al., European Society of Gastrointestinal Endoscopy (ESGE): recommendations (2009) on clinical use of video capsule endoscopy to invesigate smallbowel, esophageal and colonic diseases. Endoscopy 2010; 42:220-7.

8. VAN DER HORST-BRUINSMA I.E., NURMOHAMED M.T., Management and evaluation of extraarticular manifestations in spondyloarthritis. Ther Adv in Musculoskelet Dis 2012; 4:413-22.

9. MUSTAFA B.F., SAMAAN M., LANGMEAD L., KHASRAW M., Small bowel video capsule endoscopy: an overview. Expert Rev Gastroenterol Hepatol 2013; 7:323-9.

10. JONNALAGADDA S., PRAKASH C., Intestinal strictures can impede wireless capsule enteroscopy. Gastrointest Endosc 2003; 57:418-20.

11. MOW W.S., LO S.K., TARGAN S.R., DUBINSKY M.C., TREYZON L., ABREU-MARTIN M.T., et al., Initial experience with wireless capsule enteroscopy in the diagnosis and management of inflammatory bowel disease. Clin Gastroenterol Hepatol 2004; 2:31-40.

12. BUCHMAN A.L., MILLER F.H., WALLIN A., CHOWDHRY A.A., AHN C., Videocapsule endoscopy versus barium contrast studies for the diagnosis of Crohn's disease recurrence involving the small intestine. Am J Gastroenterol 2004; 99:2171-7.

13. CHEIFETZ A.S., KORNBLUTH A.A., LEGNANI P., SCHMELKIN I., BROWN A., LICHTIGER S., et al., The risk of retention of the capsule endoscope in patients with known or suspected Crohn's disease. Am J Gastroenterol 2006; 101:2218-22.

14. FIREMAN Z., MAHAJNA E., BROIDE E., SHAPIRO M., FICH L., STERNBERG A., et al., Diagnosing small bowel Crohn's disease with wireless capsule endoscopy. Gut 2003; 52:390-2.

15. ELIAKIM R., FISCHER D., SUISSA A., YASSIN K., KATZ D., GUTTMAN N., et al., Wireless capsule video endoscopy is a superior diagnostic tool in comparison to barium follow-through and computerized tomography in patients with suspected Crohn's disease. Eur J Gastroenterol Hepatol 2003; 15:363-7.

16. LI F., GURUDU S.R., DE PETRIS G., SHARMA V.K., SHIFF A.D., HEIGH R.I., et al., Retention of the capsule endoscope: a single-center experience of 1000 capsule endoscopy procedures. Gastrointest Endosc 2008; 68:174-80.

17. PARK S.C., CHUN H.J., KANG C.D., SUL D., Prevention and management of non-steroidal anti-inflammatory drugs-induced small intestinal injury. World J Gastroenterol 2011; 17:4647-53.

18. GOLDSTEIN J.L., EISEN G.M., LEWIS B., GRALNEK I.M., ZLOTNICK S., FORT JG., et al., Video capsule endoscopy to prospectively assess small bowel injury with celecoxib, naproxen plus omeprazole, and placebo. Clin Gastroenterol Hepatol 2005; 3:133-41.

19. KOPYLOV U., SEIDMAN E.G., Role of capsule endoscopy in inflammatory bowel disease. World J Gastroenterol 2014; 20:1155-64.

20. ZHANG W., HAN Z.L., CHENG Y., XU Y., XIAO K., LI A., et al., Value of the patency capsule in pre-evaluation for capsule endoscopy in cases of intestinal obstruction. J Dig Dis 2014; 15:345-51.

21. DELVAUX M., BEN SOUSSAN E., LAURENT V., LEREBOURS E., GAY G., Clinical evaluation of the use of the M2A patency capsule system before a capsule endoscopy procedure, in patients with known or suspected intestinal stenosis. Endoscopy 2005; 37: 801-7.

Received December 26, 2016 